\title{
A new process for sustainable wastewater treatment in Chilean copper smelters
}

\author{
Henrik K. Hansen ${ }^{1}$, Adrián Rojo ${ }^{1}$, Claudia Gutiérrez ${ }^{1}$
}

\begin{abstract}
An actual Chilean copper smelter wastewater treatment is a complex process that actually mostly is focused on fulfillment of threshold values more than sustainability. The actual wastewater treatment includes a number of precipitation, neutralization, clarifying and filtering steps. This manuscript proposes a new sustainable process that would eliminate/reduce several of the disadvantages in an actual copper wastewater treatment such as a) reduced lime addition, b) a separate gypsum and heavy metal/arsenic precipitation, c) an electrodialysis stage that would recover copper, d) an easier ferric ion dosage for arsenic removal by electrocoagulation, and e) a less reagent consuming neutralization step.
\end{abstract}

Keyword: Sustainable wastewater treatment, Electrocoagulation, Arsenic removal, Copper recovery

\section{Introduction}

The mineral processing industry in Chile has a large impact on the economic output of the country and the environmental status. The pyro metallurgic copper processing generates large amounts of arsenic that vaporize as arsenic trioxide. This compound is absorbed from the gas flow, and finally fixed as calcium or ferric arsenate, after the wastewater stream has been processed with ferric chloride or sulphate. Since the arsenic concentration in the gas phase changes due to the batch wise operation of the smelter, it is difficult to predict and control the chemical dosage for the precipitation of the arsenic compounds.

The actual concentration of arsenic and copper in copper smelter wastewater fluctuates between 5000 to $15000 \mathrm{mg} / \mathrm{L}$ and between 500 and $2000 \mathrm{mg} / \mathrm{l}$, respectively. After calcium hydroxide addition until $\mathrm{pH}$ around 10, the wastewater contains nearly no copper but $100-300 \mathrm{mg} / \mathrm{L}$ arsenic. In order to fulfil the Chilean regulations at least a concentration of $1 \mathrm{mg} \mathrm{As} / \mathrm{L}$ has to be reached. Therefore a second precipitation step with either ferric chloride or ferric sulphate is necessary together with neutralization to $\mathrm{pH}$ 7. Each precipitation step generates large amounts of contaminated sludge, which is dried and finally disposed of as a hazardous solid residue. A scheme of the actual wastewater treatment process is shown in Figure 1.

Typical concentrations of contaminants in copper smelter wastewaters are given in Table 1 (COCHILCO, 2009). In the actual treatment scheme, large amounts of solids are generated that have to be disposed of with high costs as hazardous waste. The actual treatment scheme generally fulfils the Chilean legislation for wastewater discharge but 
several disadvantages are present:

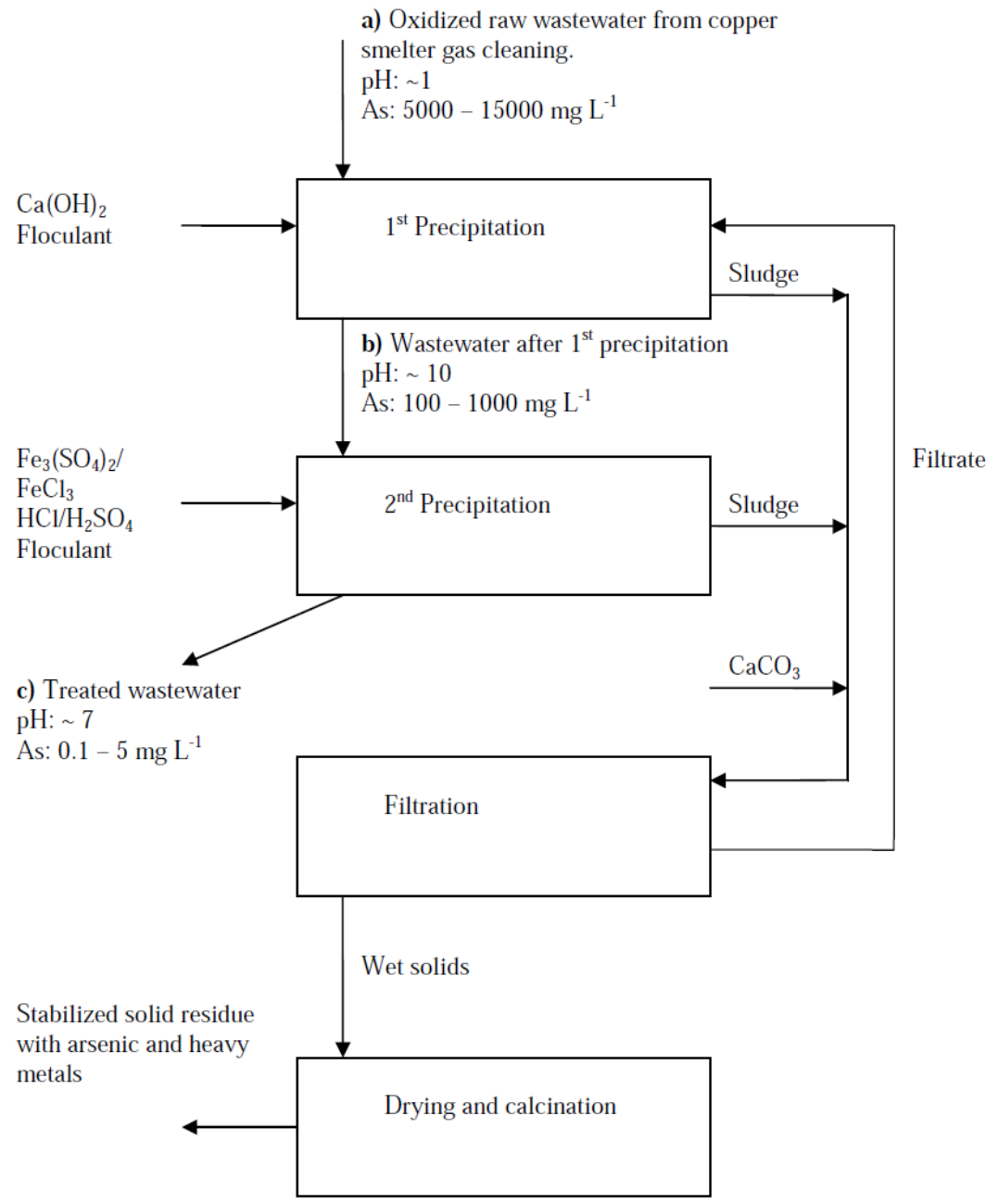

Figure 1. Actual copper smelter wastewater treatment.

Table 1. Typical composition and characteristics of copper smelter wastewater.

\begin{tabular}{|l|l|l|l|l|l|}
\hline Parameter & & Parameter & & Parameter & \\
\hline Arsenic & $5-15 \mathrm{~g} / \mathrm{L}$ & Nickel & $0.05-0.1 \mathrm{~g} / \mathrm{L}$ & $\mathrm{pH}$ & $\sim 0$ \\
\hline Copper & $0.5-2 \mathrm{~g} / \mathrm{L}$ & Bismuth & $0.05-0.1 \mathrm{~g} / \mathrm{L}$ & Volume flow & $20-30 \mathrm{~m}^{3} / \mathrm{h}$ \\
\hline Lead & $0.2-0.3 \mathrm{~g} / \mathrm{L}$ & Selenium & $\sim 0.01 \mathrm{~g} / \mathrm{L}$ & & \\
\hline Antimony & $\begin{array}{l}0.05-0.1 \\
\mathrm{~g} / \mathrm{L}\end{array}$ & Sulphuric acid & $25-100 \mathrm{~g} / \mathrm{L}$ & & \\
& & & & \\
\hline
\end{tabular}

1) In the first precipitation step huge amounts of $\mathrm{CaO}$ suspensions are added. Lime is added in excess in order to assure that copper and other heavy metals precipitate at the alkaline conditions. Typically 2-3 times more volume of lime suspension is added 
compared to the wastewater volume flow. After a clarification step after the first precipitation, considerably more wastewater is entering the second precipitation step than the first step.

2) The precipitated gypsum is contaminated with heavy metals and arsenic and therefore regarded as a solid residue. This is mixed with the arsenic containing ferric sludge after the second precipitation step, and finally dried and discharge as a hazardous waste. It would be preferable to precipitate gypsum separately from the heavy metals and arsenic.

3) Copper could be interesting to recover but in the actual process it is fixed in the huge amounts of gypsum and from there nearly impossible to recover.

4) The dosage of ferric sulphate or ferric chloride is difficult to control since the arsenic concentration in the wastewater entering the second precipitation step varies depending on the smelter operation. In some cases the arsenic content in the final treated wastewater is higher than the Chilean legislation permits for discharge, and then the treated wastewater has to be recirculated to the treatment process or used internally as process water in the smelter with a high arsenic content.

5) The $\mathrm{pH}$ profile of the wastewater in the treatment process goes from very acidic to alkaline and back to neutral. This means that acid is spent to neutralize a wastewater that initially is very acidic. It is preferable to avoid this acid addition.

At the Universidad Técnica Federico Santa Maria, environmental remediation processes have been investigated specially the use of electroremediation of soil and mine tailings (Hansen et al., 2005) and treatment of arsenic containing wastewaters (Hansen et al., 2006). Especially in wastewater treatment the electrochemical processes have shown their potential in particularly the precipitation of heavy metals and arsenic. Therefore this project suggests a new treatment scheme that would eliminate or reduce the mentioned disadvantages. Figure 2 shows the proposed process that includes a) a lime addition step to remove the majority of sulphates present, b) an electrodialysis step to separate copper from arsenic for recovery, and c) an electrocoagulation step to precipitate arsenic. These steps are described in more details in the following.

\section{First stage: Precipitation of sulphate with $\mathrm{CaO}$}

Calcium sulfate can be precipitated as dihydrate or gypsum $(\mathrm{CaSO} 4 \cdot 2 \mathrm{H} 2 \mathrm{O})$ at low temperatures and as hemihydrate $(\mathrm{CaSO} 4 \cdot 0.5 \mathrm{H} 2 \mathrm{O})$ or anhydrite $(\mathrm{CaSO} 4)$ at elevated temperatures in acidic solutions ( $\mathrm{Li}$ and Demopoulos, 2005). Kurteva and Brutskus (1961) have obtained the solubility of calcium sulfate dihydrate in different acid solutions by "the crystallization method" as described by Nyvlt (1977). In the operating field investigated by these latter researchers, calcium sulfate dihydrate mostly exists as a metastable phase whereas calcium sulfate hemihydrate and anhydrite are the unstable and the stable phases, respectively. In the operating conditions of the dihydrate process, these hydrates may undergo the following transformation: 


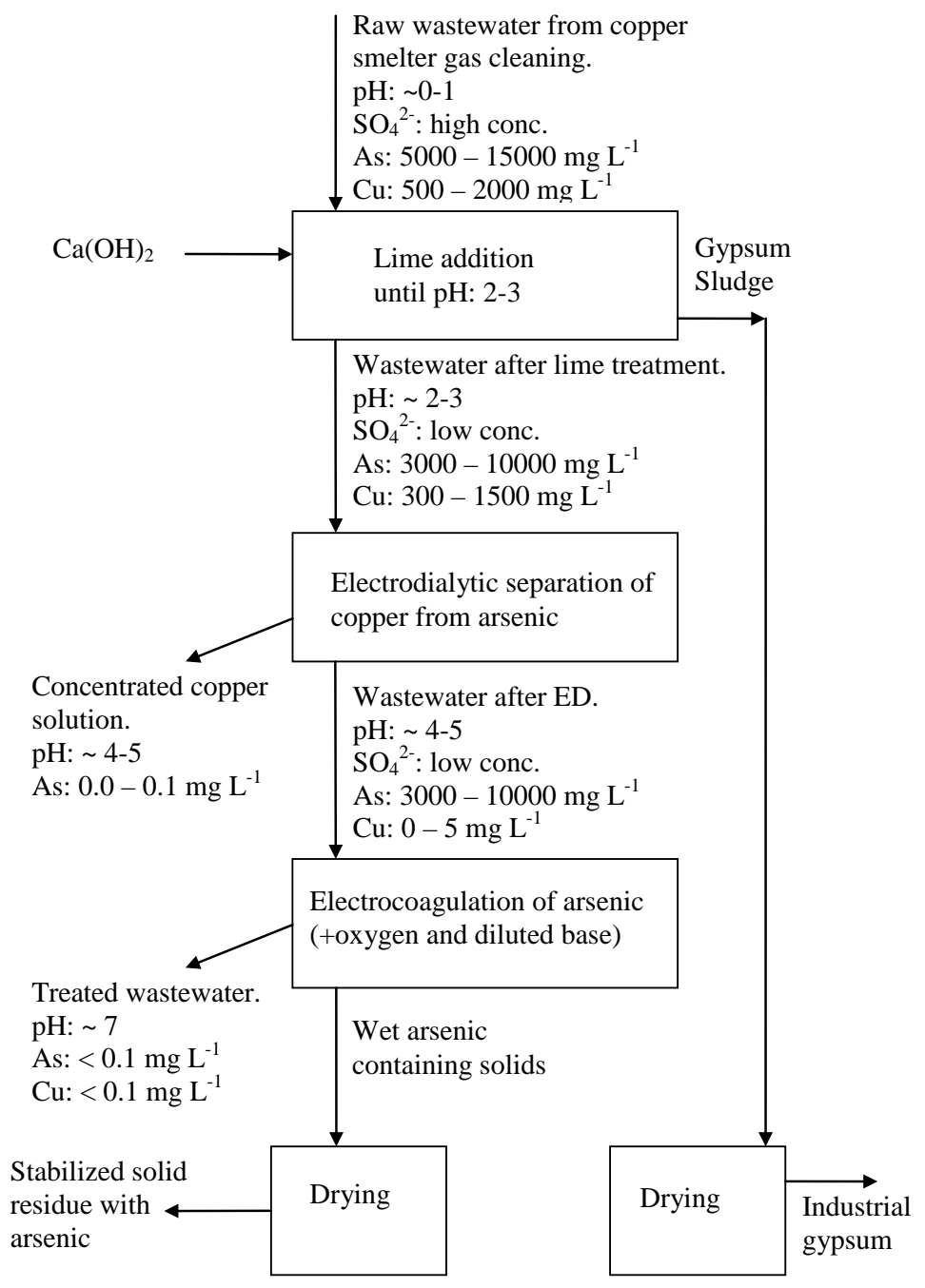

Figure 2. Proposed new copper smelter wastewater treatment.

$\mathrm{CaSO}_{4} \cdot 0.5 \mathrm{H}_{2} \mathrm{O}$ (unstable) $\rightarrow \mathrm{CaSO}_{4} \cdot 2 \mathrm{H}_{2} \mathrm{O}$ (metastable) $\rightarrow \mathrm{CaSO}_{4}$ (stable)

All calcium sulfate hydrates are relatively insoluble and they are formed wherever calcium and sulfate occur together after the equilibrium of the unstable or metastable hydrate in solution is reached (according to the Ostwald rule) (Santen, 1984). Theoretically, gypsum is the stable solid phase in water up to $45-50{ }^{\circ} \mathrm{C}$, and above that it transforms into anhydrite (Dutrizac, 2002). During sulphuric acid neutralization with calcium-containing bases which occurs below $100{ }^{\circ} \mathrm{C}$, first gypsum forms as a metastable phase because of its higher solubility, according to the Ostwald step rule, and then gradually transforms into anhydrite which has lower solubility under these conditions and consequently results 
in anhydrite scale formation downstream. Such scaling could result in serious operational problems, particularly in the solvent extraction stage.

The largest occurrence of scale-forming calcium sulphate in hydrometallurgical processes is during continuous neutralization and/or iron removal of sulphuric acid leach solutions with calcium-containing bases, such as limestone (CaCO3), and lime $(\mathrm{CaO})$. The reactions are, respectively:

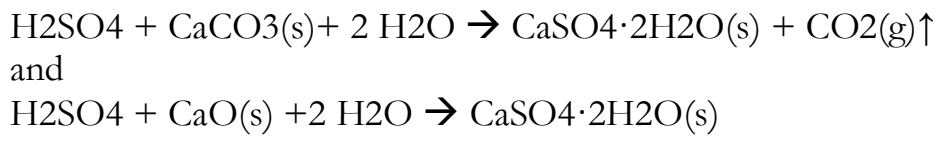

Precipitation at low supersaturation levels is relatively slow and can be induced by seeding the solution. Kinetic relations for the growth of seed crystals from solution are well established and a power law-type formulation is most commonly used (Seewoo et al., 2004):

$-\mathrm{dCA} / \mathrm{dt}=\mathrm{k}$ Ns $\left(\mathrm{CA}-\mathrm{C}^{*}\right) \mathrm{n}$

where: $\quad \mathrm{k}=$ reaction rate constant $(\operatorname{Ln}-1 /(\operatorname{moln}-1 \mathrm{~s}))$,

$\mathrm{Ns}=$ number of seed crystals,

$\left(\mathrm{CA}-\mathrm{C}^{*}\right)=$ excess solute concentration $(\mathrm{mol} / \mathrm{L})$,

$\mathrm{n}=$ order of growth.

Work at the University of Toronto (Adams and Papangelakis, 2000) found that during neutralization, scale growth was directly dependent on the degree of supersaturation in a CSTR reactor, which was in turn affected by the reactor temperature and residence time, but not the $\mathrm{pH}$. Temperature affected both the gypsum solubility and the kinetics of gypsum precipitation in the bulk slurry, which seemed to have offsetting effects on scale formation. Longer residence times led to lower supersaturation and hence lower scale growth rates. $\mathrm{pH}$ had no effect on the scale growth rate between $\mathrm{pH} 2$ and 6 . This was due to the fact that gypsum solubility is constant between these $\mathrm{pH}$ values.

Sulfates precipitate easy in low $\mathrm{pH}$ wastewater. This is confirmed by the thermodynamic equilibrium of the $\mathrm{CaSO} 4-\mathrm{Ca}(\mathrm{OH}) 2-\mathrm{H} 2 \mathrm{O}$ system (Peng et al., 2009). Here it is seen that the solubility of $\mathrm{CaSO} 4$ is below $0.4 \mathrm{~g} / 1$ at $\mathrm{pH} 2.5$. Metals such as copper and iron typically precipitates as hydroxides around and above pH 3.8 (Wang et al., 2006) and will not precipitate with sulfate below this $\mathrm{pH}$. In addition, arsenic (either in oxidation state III or V) does not precipitate with calcium cations at this low $\mathrm{pH}$. This was confirmed in an initial work on the topic (Thomas et al., 2007). Therefore it is expected that the solids formed at $\mathrm{pH} 2-3$ during $\mathrm{CaO}$ addition will be primarily be calcium sulfates. This is interesting since this would change the situation drastically in the present copper smelter wastewater treatment: from a solid considered as a hazardous waste to a valuable solid, which could be sold.

Main factors or parameters to control are the calcium sulfate precipitation with $\mathrm{pH}$ (from around 0 until 2-3) and $\mathrm{CaO}$ dosage, and to evaluate the purity/impurity of the 
precipitation product regarding the metal and arsenic content. The filtrate/solution from this treatment would be measured for final sulfate content and would enter the ED step for copper/arsenic separation.

\section{Second stage: Electrodialytic separation of copper from arsenic}

Electrodialysis (ED) has been used for decades in order to move different ions across ion exchange membranes under influence of an applied electric DC field. In this manner, ions (salts) are concentrated, solutions desalted, or ions separated selective (Xu and Huang, 2008). In the case of copper smelter wastewater ED could also be an interesting process for concentrating copper. The wastewater has typical high concentrations of copper and arsenic (see Table 1), and therefore it could be interesting to recover valuable copper but not arsenic before the final precipitation of arsenic (see Figure 1) in the actual wastewater treatment scheme. In acidic wastewater copper is present as the stable $\mathrm{Cu}^{2+}$ whereas arsenic speciation depends on the $\mathrm{pH}$ and oxidation state. Arsenic is normally present as As(III) in copper smelter wastewater (around 85\% As(III) and 15\% As(V) (Kumaresan and Riyazuddin, 2001)). At pH 0-5, As(III) would be present as $\mathrm{H}_{3} \mathrm{AsO}_{3}$ in its majority. As $(\mathrm{V})$ would be present as $\mathrm{H}_{3} \mathrm{AsO}_{4}$ at $\mathrm{pH} 0-2$, and as $\mathrm{H}_{2} \mathrm{AsO}_{4}$ at $\mathrm{pH} 2-6$, so in this project's case ( $\mathrm{pH}$ around 2-4) arsenic would be either neutral or anionic during the ED process. Anyway, presence of other substances in the wastewater would interfere with the actual speciation of arsenic, for example the presence of iron.

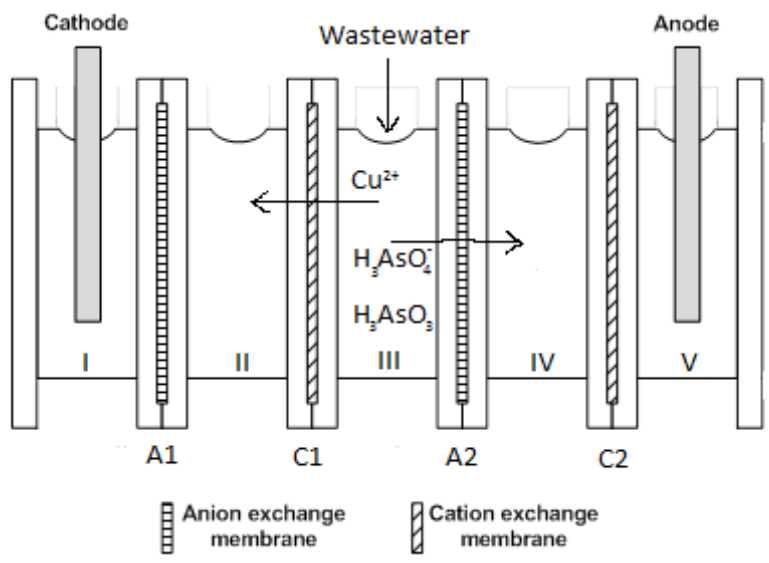

Figure 3. ED separation of $C u$ and $A$ s in copper smelter wastewater.

Some early ED work has shown the possibility to separate copper from synthetic smelter wastewaters, where copper was in excess to arsenic (Cifuentes et al., 2002). In real wastewaters the arsenic content is higher than copper. Equally, it is possible to separate copper from arsenic by ED on wood preservation contaminated soil or residues (Velizarova et al., 2002). ED has previously been shown as a method to separate sulfuric acid from very acidic sulfide smelter wastewaters (Cifuentes et al., 2002). Here the main 
transport of ions was $\mathrm{H}^{+}$and $\mathrm{SO}_{4}{ }^{2-}$ but high amounts of electric current was spent and at the current development level ED is not considered yet feasible for sulfuric acid production. In addition, it has been possible to remove sulfate and arsenic from smelter wastewater with ED combined with other processes.

Therefore, an ED process would generate the separation of copper and arsenic as presented in Figure 3. Copper would move across membrane C1 and enter the cathode concentration chamber II, whereas arsenic would either remain in chamber III or move across membrane A2 as an anionic species to chamber IV. The aim with this part of the project is to evaluate the efficiency of the copper transport during ED, the current efficiency with respect to copper, and the fate of arsenic during the process. Furthermore, it is important to follow the effect of $\mathrm{pH}$ during ED. The $\mathrm{pH}$ of the present wastewater would depend on the wastewater coming from the lime precipitation step.

\section{Third stage: Electrocoagulation of arsenic}

Electrocoagulation is by now proven to be able to treat wastewaters from different sources such as textile industries, food and protein production, soluble oil waste, restaurants, and metal finishing. Lately arsenic containing wastewater and groundwater has been treated with success using electrocoagulation (Balasubramanian and Madhavan, 2001; Hansen et al., 2008). Electrocoagulation consists of an in-situ generation of coagulants by an electrical dissolution of iron or aluminium electrodes. The generation of metallic cations takes place at the anode, whereas at the cathode, typically a $\mathrm{H}_{2}$ production occurs. The generated gas helps the flotation of flocculated particles, and therefore the process sometimes is named as electro-flocculation.

In the case of application of iron electrodes the process generates iron hydroxides, which would co-precipitate with arsenic anions and copper cations. The main electrode reactions are as shown in the following:

\section{Anodic reactions:}

a) single step oxidation of Fe into ferric ion

$\mathrm{Fe} \rightarrow \mathrm{Fe}^{3+}+3 \mathrm{e}^{-} \quad \mathrm{E}^{0}=-0.04 \mathrm{~V}$

b) a two-step process where iron is firstly oxidized to ferrous ion which, depending on anode potential, then oxidises to ferric ion:

$$
\begin{array}{ll}
\mathrm{Fe} \rightarrow \mathrm{Fe}^{2+}+2 \mathrm{e}^{-} & \mathrm{E}^{0}=-0.44 \mathrm{~V} \\
\mathrm{Fe}^{2+} \rightarrow \mathrm{Fe}^{3+}+\mathrm{e}^{-} & \mathrm{E}^{0}=0.77 \mathrm{~V}
\end{array}
$$

The second step would take place at the anode; however, it can also be promoted by the presence of other oxidants in aqueous phase:

$\mathrm{O}_{2}$ (gas) $+4 \mathrm{Fe}^{2+}+4 \mathrm{H}^{+} \rightarrow 4 \mathrm{Fe}^{3+}+2 \mathrm{H}_{2} \mathrm{O}$ (in acid solution) 
$\mathrm{O}_{2}$ (gas) $+4 \mathrm{Fe}^{2+}+2 \mathrm{H}_{2} \mathrm{O} \rightarrow 4 \mathrm{Fe}^{3+}+4 \mathrm{OH}^{-}$(in alkaline solution)

The actual occurrence of these couplings depends on the availability of dissolved oxygen.

\section{Cathodic reactions:}

$2 \mathrm{H}_{2} \mathrm{O}+2 \mathrm{e}^{-} \rightarrow \mathrm{H}_{2}+2 \mathrm{OH}^{-}$(in alkaline solution)

$2 \mathrm{H}_{3} \mathrm{O}^{+}+2 \mathrm{e}^{-} \rightarrow \mathrm{H}_{2}+2 \mathrm{H}_{2} \mathrm{O}$ (in acid solution)

Typically at the cathode the solution becomes alkaline with time. The applied current forces $\mathrm{OH}^{-}$ion migration to the anode, so the $\mathrm{pH}$ near the anode is higher than in the bulk solution, thus favouring ferric hydroxide formation:

$\mathrm{Fe}^{3+}+3 \mathrm{OH}^{-} \rightarrow \mathrm{Fe}(\mathrm{OH})_{3}$

Arsenate co-precipitates with or adsorbs to $\mathrm{Fe}(\mathrm{OH})_{3}$ :

$\alpha \mathrm{Fe}(\mathrm{OH})_{3}(\mathrm{~s})+\beta \mathrm{AsO}_{4}{ }^{3-}(\mathrm{aq}) \rightarrow\left[\alpha \mathrm{Fe}(\mathrm{OH})_{3} * \beta \mathrm{AsO}_{4}{ }^{3-}\right](\mathrm{s})$

For effective arsenate removal due to precipitation, the ratio $\alpha / \beta$ should be higher than 4 (Krause and Ettel, 1989). During electrocoagulation, iron particles are formed in the presence of $\mathrm{As}(\mathrm{V})$. This has shown to be more efficient for arsenic removal than adsorption to pre-formed $\mathrm{Fe}(\mathrm{III})$

Lytle et al., 2005). The oxidation states of As in copper smelter wastewater are As(III), arsenite, and $\mathrm{As}(\mathrm{V})$, arsenate. In the $\mathrm{pH}$ range of 4 to 10 the predominating species of $\mathrm{As}(\mathrm{V})$ present a net negative charge. On the other hand, the species of As(III) generally have no net charge (Ford, 2002). Based on this, it is expected that the $\mathrm{As}(\mathrm{V})$ removal efficiency would be higher than $\mathrm{As}(\mathrm{III})$, since the $\mathrm{As}(\mathrm{V})$ anions $\left(\mathrm{AsO}_{4}{ }^{-3}, \mathrm{HAsO}_{4}{ }^{2-}\right.$ or $\mathrm{H}_{2} \mathrm{AsO}_{4}{ }^{-}$) are adsorbed stronger by iron oxides than As(III) specie (Seidel et al., 2005). If present, it would be necessary to oxidize As(III) to $\mathrm{As}(\mathrm{V})$. Anyway, oxidised conditions in general favour arsenic removal in wastewaters.

During the electrochemical production of ferric hydroxide periodic current reversal is advisable for two reasons: a) to use two iron based electrodes which alternate as anode and cathode, both of them contributing to ferric hydroxide production. This way, they are evenly consumed during the process; b) to avoid anode passivation by periodic removal of excess ferrous and ferric ions from the vicinity of the anode and of loosely attached reaction products from the anode surface. The major problem of the iron electrode is its passivation, which is caused by iron hydroxide produced during the discharge process and prevents further anodic utilization. Passivation of the anode surface is possible in these systems due to high current densities and high concentrations of $\mathrm{Fe}^{2+}, \mathrm{Fe}^{3+}$ and $\mathrm{OH}^{-}$ions at the anode surface.

Recently the electrocoagulation process has been applied with success for arsenic removal from wastewater containing $100 \mathrm{mg} \mathrm{L}^{-1} \mathrm{As}(\mathrm{V})$ (Hansen et al., 2008). Different process designs were tested, such as a turbulent flow reactor, a combined 
electrocoagulation and sedimentation basin, and an airlift reactor. It was found (Hansen et al., 2006) analysing preliminarily the electrocoagulation process in a modified flow sedimentation basin that a removal of $98 \%$ from a $100 \mathrm{ppm}$ As solution was possible using iron electrodes. Here it was also showed that introduction of air was necessary to assure oxidation of dissolved iron. The effect of air bubbling not only oxidizes $\mathrm{Fe}^{2+}$ to $\mathrm{Fe}^{3+}$ but also promotes the coagulation/flocculation process due to turbulent conditions. It was reported (Hansen and Ottosen, 2010) that As(III) removal mechanism in electrocoagulation with iron electrodes seems to be oxidation of As(III) to As(V) and surface complexation with iron hydroxides. The airlift reactor gave most promising results but characteristics in the design showed the presence of dead volumes in the cell. In all cases turbulent conditions were obtained, which are essential for having an efficient electrocoagulation (Holt et al., 2005).

Two general drawbacks with electrocoagulation of arsenic were: a) the long remediation time and b) the precipitation of fine solids/crystals that were difficult to settle. In order to increase the arsenic removal velocity, one can increase the solid (or adsorbent) content in the wastewater during the electrocoagulation process in this manner: surface

a) introducing zero valent nanoparticles that will increase the total adsorbent

b) introducing hydrous ferric oxide adsorbing particles by electrochemical peroxidation

\section{Conclusions}

The final proposed process as shown in Figure 2 would eliminate and/or reduce the disadvantages in the actual copper smelter wastewater treatment scheme mentioned above:

1) The lime addition would be reduced considerably compared to the original treatment. It is expected that less than $50 \%$ solution is added to the wastewater flow.

2) The calcium sulphate produced would contain very low amounts of contaminating elements such as arsenic and copper.

3) Copper would be concentrated in a solution during the ED process and could be recovered by electrodepositing processes.

4) The dosage of ferric ions during EC would be easy to control by the electric current meaning that the final treated wastewater would contain less arsenic than the Chilean legislation sets as maximum value for discharge.

5) The lime addition until $\mathrm{pH} 2$ would make the first neutralization step for the wastewater. The ED and EC processes would reduce further the content of acidity, since during $\mathrm{ED}, \mathrm{H}+$ would cross cation exchange membrane $\mathrm{C} 1$ (Figure 3), and during EC, $\mathrm{OH}$ - would be produced in-situ at the anode. The final $\mathrm{pH}$ control would be minimal.

\section{References}

Adams, J.F., Papangelakis, V.G. (2000) Gypsum scale formation in continuous neutralization reactors. Canadian Metallurgical Quarterly 39, 421-432. 
Balasubramanian N. and Madhavan, K. (2001) Arsenic removal from industrial effluent through electrocoagulation, Chemical Engineering \& Technology, 24, 519-521.

Cifuentes, L., Crisóstomo, G., Ibáñez, J.P., Casas, J.M., Alvarez, F., Cifuentes, G. (2002) On the electrodialysis of aqueous $\mathrm{H} 2 \mathrm{SO} 4-\mathrm{CuSO} 4$ electrolytes with metallic impurities, Journal of Membrane Science, 207, 1-16.

COCHILCO (2009) Informe tendencias del Mercado del cobre. Tercer trimestre 2009. Dirección

de Estudios y Políticas Públicas, Comisión Chilena del Cobre. www.cochilco.cl.

Dutrizac, J.E. (2002) Calcium sulphate solubilities in simulated zinc processing solutions. Hydrometallurgy, 65, $109-135$.

Ford R.G. (2002) Rates of hydrous ferric oxide crystallization and the influence on coprecipitated arsenate, Environmental Science and Technology, 36, 2459-2463.

Hansen H.K., Rojo A., Ottosen L.M. (2005) Electrodialytic remediation of copper mine tailings, Journal of Hazardous Materials, 117, 179-183.

Hansen, H.K., Nuñez, P., Grandon, R. (2006) Electrocoagulation as a remediation tool for copper smelter wastewaters. Minerals Engineering, 19(5), 521-524.

Hansen, H.K. Nuñez, P., Jil, C. (2008) Removal of Arsenic from Wastewaters by Airlift Electrocoagulation. Part 1: Batch Reactor Experiments. Separation Science and Tecbnology, 43, 212-224.

Hansen, H.K. and Ottosen, L.M. (2010) Removal of arsenic from wastewaters by airlift electrocoagulation. Part 3: Copper smelter wastewater. Separation Science and Technology, 45, 1326-1330.

Holt, P.K., Barton G.W. and Mitchell C.A. (2005) The future for electrocoagulation as a localized water treatment technology, Chemosphere, 59(3) 355-367.

Krause, E. and Ettel, V.A. (1989) Solubilities and stabilities of ferric arsenate compounds, Hydrometallurgy, 22(3), 311-337.

Kumaresan, M. and Riyazuddin, P. (2001) Overview of speciation chemistry of arsenic, Current Science, 80, 837-846.

Kurteva, O. I. and Brutskus, E. B., (1961) Solubilities of Calcium Sulfate In $\mathrm{H}_{3} \mathrm{PO}_{4}+\mathrm{H}_{2} \mathrm{SO}_{4}$ and $\mathrm{H}_{3} \mathrm{PO}_{4}$ $+\mathrm{H}_{2} \mathrm{SiF}_{6}$ acid Mixtures. Zh.Prikl. Khim.34,1714-1718.

Li, Z. and Demopoulos, G.P., (2005) Solubility of $\mathrm{CaSO} 4$ phases in aqueous $\mathrm{HCl}+\mathrm{CaCl}_{2}$ solutions from 283 K to 353 K. J. Chem. Eng. Data, 50, 1971-1982.

Lytle, D.A., Sorg, T.J., Snoeyink, V.L. (2005) Optimizing arsenic removal during iron removal: Theoretical and practical considerations. Journal of W ater Supply: Research and Technology-AQUA, 54(8), 545-560.

Nyvlt, J. (1977) Solid-liquid Equilibria; Elsevier: Amsterdam, The Netherlands.

Peng X.Y., Wang Y.Y., Chai L.Y., Shu Y.D. (2009) Thermodynamic equilibrium of CaSO4-Ca(OH)2-H2O system, Trans. Nonferrous Met. Soc. China, 19, 249-252.

Santen, R.A. (1984). The Ostwald step rule. J. Phys. Chem. 88, 5768-5769.

Seewoo, S., Van Hille, R., Lewis, A. (2004) Aspects of gypsum precipitation in scaling waters, Hydrometallurgy, $75,135-146$.

Seidel H., Gorsch K., Amstatter K., Mattusch J. (2005) Immobilization of arsenic in a tailings material by ferrous iron treatment, $W$ ater Research, 39, 4073-4082.

Thomas, S.Y., Choong, T.G., Chuah, Y., Robiah, F.L., Koay, G., Azni, I. (2007) Arsenic toxicity, health hazards and removal techniques from water: an overview, Desalination, 217 (2007) 139-166.

Velizarova, E., Ribeiro, A.B., Ottosen, L.M: (2002) A comparative study on $\mathrm{Cu}$, $\mathrm{Cr}$ and As removal from CCA-treated wood waste by dialytic and electrodialytic processes, Journal of Hazardous Materials, 94, 147-160.

Wang, C., Ma, S., Lu, A., Zhou, J. (2006). Experimental study on formation conditions of ammoniojarosite and its environmental significance. Acta Geol. Sin. 80, 296-301.

Xu, T. and Huang, C. (2008) Electrodialysis-Based Separation Technologies: A Critical Review, AIChE Journal, 54, 3147-3159. 